\title{
OPTIMIZATION OF CARBOPOL 940 AND PROPYLENE GLYCOL CONCENTRATION ON THE CHARACTERISTIC AND INHIBITORY EFFECT OF ETHANOL EXTRACT GEL OF PAPAYA (Carica papaya L.) SEEDS AGAINST Staphylococcus aureus
}

\author{
Octavianus Yandri*), Wahyuning Setyani \\ Faculty of Pharmacy, Universitas Sanata Dharma, Campus 3 Paingan, Maguwoharjo, Depok, \\ Sleman, Yogyakarta, 55282
}

Received April 26, 2020; Accepted December 20, 2020

\begin{abstract}
Papaya (Carica papaya L.) seeds contain alkaloids, flavonoids, tannins, phenolic compounds and saponins have been proven its synergistic effect in inhibiting the growth of Staphylococcus aureus. In this research, ethanol extract of papaya seeds was formulated in gel preparations. Optimization of the composition of the gelling agent and humectant was carried out to obtain the gel preparation of papaya seed ethanol extract with good physical properties and stability. The parameters used to determine the stability of the preparation are Physical properties which include viscosity, spreadability, and percentage of viscosity shift. Data analysis was performed using Design-Expert software version 12 and SPSS. The inhibitory activity test was carried out by the disk-diffusion agar method with Staphylococcus aureus ATCC 25923 as the test bacteria. The results of the inhibitory activity test of papaya seed ethanol extract at a concentration of $20 \%$ had moderate activity and at concentrations of $40 \%, 60 \%, 80 \%$ and $100 \%$ classified as strong against the Staphylococcus aureus. Carbopol 940 is dominant factor in influencing the response of viscosity $(92.504 \%)$ and spreadability (59.539\%). Preparations with good physical properties andstability were obtained on the use of carbopol 940 and propylene glycol as much as 1.06604 grams and 13.2146 grams respectively.
\end{abstract}

Keywords: antibacterial; factorial design; papaya seeds; Staphylococcus aureus.

\section{INTRODUCTION}

Staphylococcus aureus is a Grampositive bacteria found in a healthy human skin surface of about $20 \%$. The Staphylococcus aureus is a major bacterial human pathogen that causes a wide variety of clinical manifestations such as skin and tissue infections, skin abscesses, purulent cellulitis, acne, impetigo, and wound infections (Nismawati et al., 2018). Amoxicillin, a penicillin derivative, is an antibacterial group of $\beta$-lactams that is often used to overcome the Staphylococcus aureus infection. The penicillin is very effective in dealing with Staphylococcus infections and has been used in medicine since the 1940s, but in 1942 cases of Staphylococcus aureus resistance were discovered in hospitals. The Staphylococcus aureus resistances to penicillin derivatives occur in more than $86 \%$ of cases and lead to therapeutic failure (Setiawati, 2015).

Based on the factors causing this infection problem, it becomes a potential target for the development of research related to natural materials that have antibacterial activity and will be used as natural antibacterials. The antibacterial from

*Corresponding author: Octavianus Yandri

Email: octavianusyandri@gmail.com 
natural materials is expected to overcome Staphylococcus aureus infection as effective as synthetic antibacterial without increasing the risk of bacterial resistance to synthetic antibacterial. Papaya seeds that become waste are still rarely used, whereas based on research conducted by Torar et al. (2017) states that ethanol extract of papaya seed contains secondary metabolites such as alkaloids, flavonoids, tannins, phenolic compounds and saponins which have been shown to have antibacterial activity at $20 \%$, $40 \%, 60 \%$ and $80 \%$ concentration with classified as moderate potency against Staphylococcus aureus.

In this research the pepeya seed ethanol extract was formulated as a gel, which has never been reported before. Gels aresemisolid systems that consist of eithersuspension of small inorganic particles or large organic molecules interpenetrated by a liquid (Dirjen POM RI, 2013). Part of the preparations that greatly affect physical quality and stability of the gel preparations are gelling agents and humectants. The gelling agent will form a structural system which is a very important factor in the gel. The humectants maintain the stability of the gel preparation by absorbing moisture andreducing water evaporation from the gel preparation (Sayuti, 2015). Carbopol is a synthetic polymer of acrylic acid which has ahigh molecular weight and acts as a gelling agent in the concentration range of $0.5 \%$ $2 \%$ (Rowe et al., 2009). The use of carbopol 940 as a gelling agent is consideredbecause of its high stability, resistance to microbial attack and widely used in the pharmaceutical and cosmetic industries. The efficiency of carbopol 940 is very good, so that low levels can provide a significant viscosity response (Allen and Ansel, 2002). The propylene glycol is a humectant in the form of clear liquid, colorless, thick, practically odorless, with a sweet taste, rathersharp like glycerin. The propylene glycol is acommon solvent that is better than glycerin and dissolves various ingredients, such as phenols, sulfa drugs, vitamins (A and D) and most alkaloids.
The propylene glycol is used in various pharmaceutical dosage form and generally considered as a relatively non-toxicingredient (Rowe et al., 2009). The use of gelling agents and humectants with different compositions in the gel preparationformulations can have an effect on the physical properties and stability of the gel preparations, therefore it is necessary to optimize the composition of the gelling agent and humectants to obtain the optimum compositions range of carbopol 940 and propylene glycol to obtain the gel preparations which has good physical properties and stability. Factorial design isone of methods that can be used for determining the composition of gelling agents and humectants to obtain gel preparations with good physical properties and stability. Factorial design is widely used in experiments, especially in industry,because it can determine the influence of main factors and interactions on responsesand observe the simultaneous effects of several factors and their interactions (Tantri et al., 2015).

\section{METHODS \\ Instrumentations and materials}

The instrumentations used in this research were analytical balance (Nagata), oven (memert UF 260 and WTC Binder), Viscometer (Rheosys Micra Merlyn VR), rotatory evaporator (BUCHI Rotavator R300), whatman filter paper no. 1, freezer (Samsung), hotplate (IKA C-MAG HS 7), micropipette (Pipetman Kit), spreader, paper disc, Biological Safety Cabinet/BSC (Model LA2-3A1-E; Series 95067; Brand ESCO Class II type A2); Biological Safety Cabinet used to protect personnel against biohazardous or infectious agents and to help maintain quality control of the material being worked with as it filters both the inflow and exhaust air., autoclave (KT-40; ALP), magnetic stirrer, homogenizer, vortex, Laminar Air Flow Biolus CLB-201S, nephelometer (Phoenix Spec Ref 440910), Vacuum (Gast DOA-P504 BN) and $\mathrm{pH}$ meter (pH 3310 SET 2 inc. SenTix 41). The 
materials used in this research were California variety papaya seeds, ethanol $95 \%$, mayer reagent, aquadest, $\mathrm{FeCl}_{3} 1 \%, \mathrm{NaOH} 10 \%$, Nutrient Agar (Merck 105450) and Nutrient Broth media (Merck 105443), Mc Farland II standard solution, Buffered Peptone Water, ethanol $70 \%$ and $10 \%$ Dimethyl Sulfoxide solution (pharmaceutical grade), Carbopol 940 (pharmaceutical grade), Propylene glycol (pharmaceutical grade), methylparaben and triethanolamine / TEA (pharmaceutical grade).

\section{The collecting and determination ofpapaya plants (Carica papaya L.)}

The purpose of plant determination is to match the morphological characteristics that exist in plants used in this research with comparison to the book Flora of Java so that there is no mistake in taking plants used for the research (Andriyani et al., 2010). The California (variety) papaya plants were obtained from the Educational Tourist Village plantations of Pandowoharjo, Sleman, Yogyakarta. Determination of papaya plants was carried out at the Department of Pharmacy Biology, Faculty of Pharmacy, Gadjah Mada University, Yogyakarta.

\section{The pollination of papaya seeds (Carica papaya $\mathbf{L}$.)}

Papaya seeds were washed clean and discarded seed coatings, after that weigh and record the results. Papaya seeds drying is done using the oven with $50{ }^{\circ} \mathrm{C}$ of temperature for 24 hours. Papaya seeds that have been dried are pulverized using a blender and then sieved to obtain a powder with the same size (Torar et al., 2017).

\section{The measurement of water content of papaya seed powder}

The measurement of the water content of papaya seed powder was performed using moisture balance instrument, by inserting 5 grams of papaya seed powder into the instrument at temperature of $120^{\circ} \mathrm{C}$ and wait for the value of the water content appears constant number $(\%)$. The water content in simplicia powder must not exceed $10 \%$, this is intended to avoid the rapid growth of fungi in extracts (Kartikasari et al., 2014).

\section{Production of the papaya seed ethanol extract}

Extracts were made by weighing 85 grams of dried papaya seed powder, then macerated using $95 \%$ ethanol as much as 500 $\mathrm{mL}$ in an erlenmeyer and covered with aluminium foil then left for 4 days while stirring occasionally, next filtered with filter paper to produce filtrate (1) and residue. The residue was then macerated again (remaceration) with $250 \mathrm{~mL}$ of $95 \%$ ethanol, then the erlenmeyer was covered with aluminium foil and left for 2 days while occasionally stirring. After 2 days, the sample was filtered to produce filtrate (2). The filtrate (1) and the filtrate (2) were mixed together and then evaporated using a rotary evaporator until a thick extract wasobtained (Torar et al., 2017).

\section{Qualitative phytochemical screening}

Test for Flavonoids: about $1 \mathrm{~mL}$ extract was added with a few drops of $10 \% \mathrm{NaOH}$. The appearance of orange showed the presence of flavonoids (Ikalinus et al., 2015).

Test for Tannins: the extract was boiled with $20 \mathrm{~mL}$ of water and then filtered. A few drops of $\mathrm{FeCl}_{3}$ were added to the sample. Positive reaction for tannin was claimed if greenishbrown or black-blue color appearance (Patel et al., 2014).

Test for Saponin: the extract was boiled with $20 \mathrm{~mL}$ of water in a water bath. The extract was shaken and allowed to stand for 15 minutes. The formation of a stable foam showed positive samples containing saponins (Ikalinus et al., 2015).

Test for Alkaloids: about $1 \mathrm{~mL}$ of extract was added 2 drops of Mayer's reagent solution. The formation of white or yellow lumpy deposits showed the presence of alkaloids (Ikalinus et al., 2015).

Test for Phenolic: the extract is diluted to $5 \mathrm{ml}$ with distilled water. Then add a few dropsof neutral $5 \% \mathrm{FeCl}_{3}$ solution. The dark green color indicates the presence of phenolic compounds (Lohidas et al., 2015). 


\section{The antibacterial activity test}

Antibacterial activity test was carried out by the diffusion method to using paper discs (6 $\mathrm{mm}$ diameter) and the test bacterial Staphylococcus aureus ATCC 25923. The bacterial suspension was made by mixing the bacterial culture into the Buffer PeptonWater, then measured on a nephelometer to equalize the number of bacteria equivalent to $6 \times 10^{8}$ $\mathrm{CFU} / \mathrm{mL}$ (Mc Farland II standard solution). The concentration series of papaya seed ethanol extract was prepared by dissolving the extract into DMSO with a percentage of $\mathrm{w} / \mathrm{v}$, for example the ethanol extract of papaya seeds with a concentration of $20 \%$ was prepared by weighing 1 gram of the extract and dissolving it in $5 \mathrm{~mL}$ of DMSO.

The paper disc was dipped in $1 \mathrm{~mL}$ of the papaya seed ethanol extract and then placed on the surface of NA media inoculated with $0.2 \mathrm{~mL}$ of Staphylococcusaureus ATCC 25923 with a concentration of $6 \times 10^{8} \mathrm{CFU} /$ $\mathrm{mL}$. Incubation was carriedout at $37^{\circ} \mathrm{C}$ for 1 x 24 hours. 1\% ampicillin and 10\% DMSO solution was use as positive control and negative control respectively. 3 times replications were applied fot the tests. Observations were made on the irradical inhibition zone formed around the paper disc (Muharni et al., 2017).

\section{Formulation of gel of papaya seed ethanol extract}

Aseptic preparation of gel preparations was carried out in Laminar Air Flow (LAF). The gel formulation process began by dispersing carbopol 940 over $50 \mathrm{~mL}$ of aquadest heated to a temperature of $70{ }^{\circ} \mathrm{C}$, the carbopol was allowed to expand and then stirred using a stamper until homogeneous.

Then triethanolamine and propylene glycol were added, stirred until homogeneous and a clear gel mass was obtained. $15 \mathrm{~mL}$ methylparaben was added and stirred until homogeneous. The last step was addition ethanol extracts of papaya seed and remaining aquadest while continuing stirred until the gel was homogeneous (Sarlina et al., 2017).
The evaluation of the physical properties and stability of gel preparations Organoleptic and homogeneity

Organoleptic tests of the gel were carried out by observations of shapes, colors and odors visually (Salman et al., 2012). Homogeneity test was carried out by weighing gel preparations as much as $0.1 \mathrm{~g}$ and then smeared on glass objects or other suitable transparent material, the composition was observed (Salman et al., 2012).

$p H$

The $\mathrm{pH}$ test was carried out using a $\mathrm{pH}$ meter. Calibration of the $\mathrm{pH}$ meter was done with 2 standard buffers with $\mathrm{pH} 4.01$ and 7.00. The electrodes were rinsed withdistilled water and dried. Measurement of thepH of the gel was done by weighing as much as $1 \mathrm{~g}$ of the gel preparation and then diluted with distilled water to $10 \mathrm{ml}$. The electrodes were dipped in the gel solution, allowed to a constant number. The number shown by the $\mathrm{pH}$ meter was the $\mathrm{pH}$ value of the preparation (Salman et al., 2012).

\section{Spreadability}

The gel spreadability test was carried out by weighing the gel as much as 0.5 gram and then placed in the middle of a scaledglass. On top of the gel was placed another glass or other transparent material and added a load of 150 grams, allowed to stand for 1 minute, then measured the distribution diameter (Sayuti, 2015).

Viscosity

Viscosity measurements in this research were carried out using the Rheosys instrument and done by placing the gel preparation in a viscometer container untilthe spindle is submerged (Sayuti, 2015). The use of Rheosys instrument also aimed to determine the flow properties of papaya seed ethanol extract gel.

Freeze-Thaw Cycling

The physical stability test of the gel preparation was carried out by the Freeze and Thaw cycle test by storing the gel preparation at $4 \pm 2{ }^{\circ} \mathrm{C}$ for 24 hours, and thencontinued by storing the gel preparation at $45 \pm 2{ }^{\circ} \mathrm{C}$ for 24 hours ( 1 cycle), testing was 
carried out in 3 cycles and physical changes were observed at the beginning and end of the cycle which included organoleptic, viscosity, spreadability, and $\mathrm{pH}$ (Warnida et al., 2016). The stability was to be good if there was no change in physical properties and shifts in viscosity (Salman et al., 2012).

\section{RESULTS AND DISCUSSION}

The rendemen of Carica papaya L. ethanol extract

The fixed weight of the extract was 94.7119 grams. Extract yield was the ratio of extract to simplicia weight. Determination of the yield aimed to determine the amount of approximately simplicia needed for the manufacture of a certain amount of thick extract (Farmakope Herbal Indonesia, 2008).

The extract yield was $23.33 \%$ obtained from the calculation of 94.7119 grams of extract and 405.95 grams of dried papaya seed powder. The extract yield was in accordance with research conducted by Hayatie et al. (2015) which states that the content of secondary metabolites in papaya seeds is classified as small, namely alkaloids by $14.54 \%$, flavonoids, $0.9 \%$ and tannin $0.78 \%$.

\section{The qualitative phytochemical screening}

In this research, the phytochemical screening results showed that the ethanol extract of papaya (Carica papaya L.) seeds contained alkaloids,flavonoids, tannins, phenolic compounds and saponins (presented in Table 1). The results of the phytochemical screening were in accordance with research conducted by Lohidas et al. (2015) which states that papaya seed ethanol extract contains secondary metabolites such as alkaloids, flavonoids, tannins, phenolic compounds and saponins.
Table 1. Phytochemical screening results
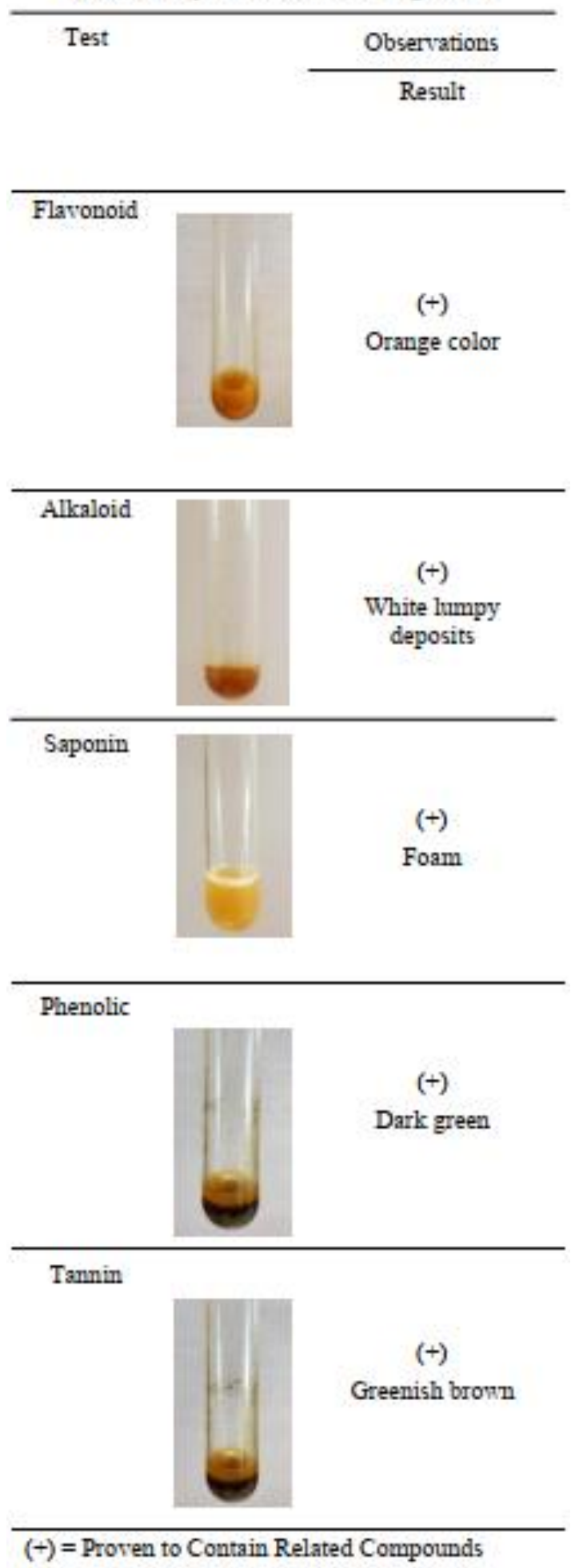


\section{The antibacterial activity results}

Measurement of the inhibition zone (irradical zone) refers to Hudzicki (2016), where the value of the measured inhibition zone is immediately recorded without reducing the diameter value of the paper disc.

Table 2. Inhibitory activity against Staphylococcus aureus

\begin{tabular}{cc}
\hline $\begin{array}{c}\text { Extract } \\
\text { Concentration }\end{array}$ & $\begin{array}{c}\text { Average of the Irradical } \\
\text { Inhibition Zone (mm) }\end{array}$ \\
\hline $20 \%$ & 9.67 \\
\hline $40 \%$ & 11.33 \\
\hline $60 \%$ & 12.67 \\
\hline $80 \%$ & 14.33 \\
\hline $100 \%$ & 16.33 \\
\hline Positive Control & 14.33 \\
\hline Negative Control & 0 \\
\hline Growth Control & Good bacterial growth \\
\hline Contamination & No Contamination \\
\hline Control & \\
\hline $\begin{array}{l}\text { Positive Control = } 1 \% \text { Ampicillin } \\
\text { Negative Control = } 10 \% \text { DMSO }\end{array}$
\end{tabular}

In this research, the results of the test for the inhibitory activity of the ethanol extract of papaya seeds that has been presented in Table 2, which at a concentration of $20 \%$ had moderate activity against Staphylococcus aureus bacteria, while the papaya seed ethanol extract with a concentration of $40 \%, 60 \%, 80 \%$, and $100 \%$ had activity classified as strong against Staphylococcus aureus bacteria according to Davis and Stout criteria.

\section{The gel formulation}

The gel formula in this research refers to research from Arikumalasari et al. (2013). The difference in the formula in this research with the reference formula was found in the extract used, the type of gelling agent and the number of preservatives used. In this research papaya seed ethanol extract gel preparations has not activity against Staphylococcus aureus because the antibacterial activity test was only carried outon the extract, not on the gel preparation. In the gel formula, a $20 \%$ concentration of ethanol extract was used because at aconcentration of $20 \%$ it already had moderate activity in inhibiting the activity of Staphylococcus aureus. In addition, the use of a concentration of $20 \%$ is also in order to increase the concentration slowly over time. The formulas have been presented in Table 3.

Table 3. Formulas of gel of papaya seed ethanol extract

\begin{tabular}{|c|c|c|c|}
\hline Ingredients & F1 $(g)$ & FA $(\mathrm{g})$ & FAB $(\mathrm{g})$ \\
\hline $20 \%$ Papaya seeds ethanol extract & $5 \mathrm{~mL}$ & $5 \mathrm{~mL}$ & $5 \mathrm{~mL}$ \\
\hline Carbopol 940 & 0.75 & 1.75 & 1.75 \\
\hline Propylene glycol & 10 & 10 & 15 \\
\hline TEA & 4 & 4 & 4 \\
\hline Methylparaben & 0.05 & 0.05 & 0.05 \\
\hline Aquadest & add 100 & add 100 & add 100 \\
\hline
\end{tabular}




\section{The evaluation of the physical properties}

Organoleptic test results and homogeneity of papaya seed ethanol extract gel preparations for the four formulas fulfilled good gel preparation criteria in terms of organoleptic aspects and homogeneity, which were clear yellowish- brown, the typical odor of extract, homogeneous and no syneresis occurred.

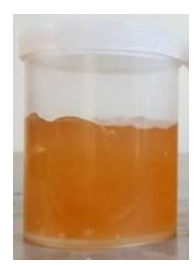

Figure 1. The physical appearance of antibacterial gel of papaya seed ethanol extract

The $\mathrm{pH}$ test is carried out to see the acidity level of the gel preparation to ensure the gel preparation does not irritate the skin due to $\mathrm{pH}$ that is too low or too high. The $\mathrm{pH}$ of the preparation according to skin $\mathrm{pH}$ criteria is in the interval 4.5 - 6.5 (Sayuti, 2015). The results of the $\mathrm{pH}$ test of papaya seed ethanol extract gel after storage cycle 0 to after 3 cycles of freeze and thaw showed that the $\mathrm{pH}$ of the preparation was stable (Table 4).

Table 4. The $\mathrm{pH}$ value of gel of papaya seed ethanol extract

\begin{tabular}{cccccc}
\hline \multirow{6}{*}{ Formula } & \multicolumn{6}{c}{$\mathrm{pH}$} \\
\cline { 2 - 6 } & $\mathrm{C} 0$ & $\mathrm{C} 1$ & $\mathrm{C} 2$ & $\mathrm{C} 3$ & $\mathrm{SD}$ \\
\hline F1 & 4.9 & 4 & 4.9 & 4.9 & 0.009 \\
\hline FA & 5 & 5 & 5 & 5 & 0.012 \\
\hline FB & 5.3 & 5.3 & 5.3 & 5.2 & 0.029 \\
\hline FAB & 5.5 & 5.5 & 5.5 & 5.5 & 0.017 \\
\hline *C0 = Cycle 0, C1 & Cycle 3, SD $=$ Standard $1, \mathrm{C} 2=$ Cycle 2, C3 $=$ \\
\end{tabular}

The resistance of a liquid to flow is expressed by viscosity. The higher the viscosity value, the higher the resistance of a liquid to flow (Sinko, 2011). Good viscosity of gel preparations is $2-4 \mathrm{~Pa}$.s. The viscosity of the gel is too high (thick) will cause the gel preparation is difficult to remove from the container, whereas if theviscosity of the gel preparation is too low then the duration of the gel preparation staying on the skin is getting shorter.

Table 6. The results of viscosity test for gel of papaya seed ethanol extract

\begin{tabular}{cccc}
\hline F & C0 (Pa.s) & C3 (Pa.S) & VS (\%) \\
\hline F1 & $2.42 \pm 0.02$ & $2.43 \pm 0.01$ & $0.76 \pm 0.6$ \\
\hline FA & $3.43 \pm 0.02$ & $3.44 \pm 0.02$ & $0.62 \pm 0.1$ \\
\hline FB & $2.40 \pm 0.01$ & $2.38 \pm 0.01$ & $0.63 \pm 0.5$ \\
\hline FAB & $3.09 \pm 0.05$ & $3.05 \pm 0.04$ & $1.12 \pm 0.7$ \\
\hline \multirow{4}{*}{$*$ C0 $=\begin{array}{c}\text { Cycle 0, C3 = Cycle 3, F = Formula } \\
\text { VS = Viscosity Shift }\end{array}$} \\
\hline \multicolumn{4}{c}{}
\end{tabular}

Formula A has the composition of carbopol 940 at a high level (1.75 grams) and propylene glycol at a low level (10 grams) so that the resulting viscosity value is high. In all four formulas it is known that formula B has the lowest viscosity value. This is because formula B contains the composition of propylene glycol at a highlevel (15 grams) and has a carbopol 940 content at a low level (0.75 gram), causing the viscosity value of the gel preparation to be low (Table 5). In this research after analyzing the data using Design-Expert software, it is known that carbopol 940 provides the greatest effect on influencing the viscosity response and has a contribution to the viscosity response of $92.509 \%$. The effect of carbopol 940 showed that it has an influence in increasing the viscosity of papaya seed ethanol extract gel. 
Table 5. Effects of both factors and their interactions on viscosity response

\begin{tabular}{cccc}
\multicolumn{4}{c}{ interactions on viscosity response } \\
\hline Factor & Effect & \% Contribution & p-value \\
\hline $\mathbf{X}_{\mathbf{1}}$ & 2.901 & 92.5094 & $<0.001$ \\
\hline $\mathbf{X}_{\mathbf{2}}$ & 0.134 & 4.27182 & $<0.001$ \\
\hline $\mathbf{X}_{\mathbf{1}} \mathbf{X}_{\mathbf{2}}$ & 0.101 & 3.21874 & $<0.001$ \\
\hline$* \mathrm{X}_{1}=$ Carbopol 940 Factor, $\mathrm{X}_{2}=$ Propylene glycol \\
Factor, $\mathrm{X}_{1} \mathrm{X}_{2}=$ Interaction of carbopol 940 and \\
propylene glycol Factor
\end{tabular}

The spreadability test was carried out to ensure the equal distribution of the gel when applied to the skin. Good gel dispersion is in the range of 5-7 cm (Sayuti, 2015). Based on the results of the spreadability test the spread value for formula 1 , formula $B$ and formula $\mathrm{AB}$ are in the desired spread range for a gel preparation that is $5-7 \mathrm{~cm}$ (Table 7).

Table 7. The results of spreadability test for gel of papaya seed ethanol extract

\begin{tabular}{|c|c|c|c|}
\hline $\mathbf{F}$ & $\mathrm{Co}(\mathrm{cm})$ & $\mathrm{C3}(\mathrm{cm})$ & SS (\%) \\
\hline F1 & $5.41 \pm 0.04$ & $5.42 \pm 0.04$ & $0.90 \pm 0.4$ \\
\hline FA & $4.50 \pm 0.03$ & $4.43 \pm 0.04$ & $1.55 \pm 0.6$ \\
\hline FB & $6.23 \pm 0.03$ & $6.2 \pm 0.1$ & $0.53 \pm 0.2$ \\
\hline FAB & $5.25 \pm 0.03$ & $5.23 \pm 0.03$ & $0.79 \pm 0.6$ \\
\hline \multicolumn{4}{|c|}{$\begin{array}{c}* \mathrm{C} 0=\text { Cycle } 0, \mathrm{C} 3=\text { Cycle } 3, \mathrm{SS}=\text { Spreadability } \\
\text { Shift, } \mathrm{F}=\text { Formula }\end{array}$} \\
\hline
\end{tabular}

The spreadability of formula A gel was not included in the criteria of good gel dispersion accordance with the theory that the higher the viscosity value, the lower the spread power value, therefore formula $\mathrm{A}$ has the lowest spread value due to viscosity formula A was the highest viscosity of all formulas. The composition of Carbopol 940 in formula $\mathrm{A}$ is at a high level (1.75 gram) while the composition of propylene glycol at a low level (10 grams) so that the effects caused by Carbopol 940 were more dominant by which high viscosity and low value of the spread of formula A were obtained (Table 5). In this research after analyzing the data using
Design-Expert software, it was found that carbopol 940 provided the greatest effect in influencing the spreadability response and has a contribution to the spreadability response of $59.5387 \%$ (Table 8). The effect caused by carbopol 940 showed that carbopol 940 has an effect in reducing the spreadability of papaya seed ethanol extract gel.

Table 8. Effects of both factors and their interactions on spreadability response

\begin{tabular}{cccc}
\hline Factor & Effect & \%Contribution & p-value \\
\hline $\mathbf{X}_{\mathbf{1}}$ & -0.946 & 59.5387 & 0.0028 \\
\hline $\mathbf{X}_{\mathbf{2}}$ & 0.779 & 40.4046 & 0.0344 \\
\hline $\mathbf{X}_{\mathbf{1}} \mathbf{X}_{\mathbf{2}}$ & -0.029 & 0.0566 & 0.8947 \\
\hline$* \mathrm{X}_{1}=$ Carbopol 940 Factor, $\mathrm{X}_{2}=$ Propylene glycol \\
Factor, $\mathrm{X}_{1} \mathrm{X}_{2}=$ Interaction of Carbopol 940 and \\
Propylene glycol Factor
\end{tabular}

\section{The parameter of gel stability}

Based on the data presented in Table 9, it can be concluded that there was no significant change in the viscosity value after cycle 0 and cycle 3 of the freeze and thaw treatment for the four gel preparation formulas, thus the gel was stable.

Table 9. Statistical test results (T-test) for viscosity of papaya seed ethanol extract gel

\begin{tabular}{cc}
\hline Formula & $P$-value \\
\hline F1 & 0.706 \\
\hline FA & 0.695 \\
\hline FB & 0.096 \\
\hline FAB & 0.406 \\
\hline
\end{tabular}

In addition, based on the results of the viscosity and spreadability test that has been presented in Table 6 and 7, it can be seen that the four formulas have good viscosity and spreadability shift values where the expected percentage shift in viscosity and spreadability was $<10 \%$, thus the gel preparation was claimed stable (Yuliani, 2010). 
Effects of both factors and their interactions on viscosity shifts after 3 cycles of freeze and thaw.

In the Design-Expert software it can be directly known percentage of the two factors contribution and their interactions with the resulting shift in the viscosity.

Table 10. Effects of both factors and their interactions on viscosity shifts

\begin{tabular}{cccc}
\hline Factor & Effect & \% Contribution & p-value \\
\hline $\mathbf{X}_{\mathbf{1}}$ & 0.174 & 18.5090 & 0.0049 \\
\hline $\mathbf{X}_{\mathbf{2}}$ & 0.185 & 21.0450 & 0.0020 \\
\hline $\mathbf{X}_{\mathbf{1}} \mathbf{X}_{\mathbf{2}}$ & 0.314 & 60.4464 & $<0.001$ \\
\hline$* \mathrm{X}_{1}=$ Carbopol 940 Factor, $\mathrm{X}_{2}=$ Propylene glycol \\
Factor, $\mathrm{X}_{1} \mathrm{X}_{2}=$ Interaction of Carbopol 940 and \\
Propylene glycol Factor
\end{tabular}

Based on the data presented in Table 10 it is known that carbopol 940 can increase the viscosity shift response with a contribution of $18,509 \%$ and propylene glycol increases the viscosity shift response with a contribution of $21,045 \%$ while the interaction of both can increase the viscosity shift response with a contribution of $60.446 \%$. Carbopol 940 and propylene glycol factors and their interactions were stated to significantly influence the shift in viscosity produced during the research because they had a $p$-value $<0.05$.

\section{Determination of optimum area}

In this research the determination of the optimum area was carried out using DesignExpert software by plotting the contour plot viscosity response and the scattered power response obtained so that the overlay plot was found as the optimum area in this research. The yellow color in the overlay plot indicates that the formula is within the desired range or research parameters, while the grey color states that the formula is not within the desired research range.

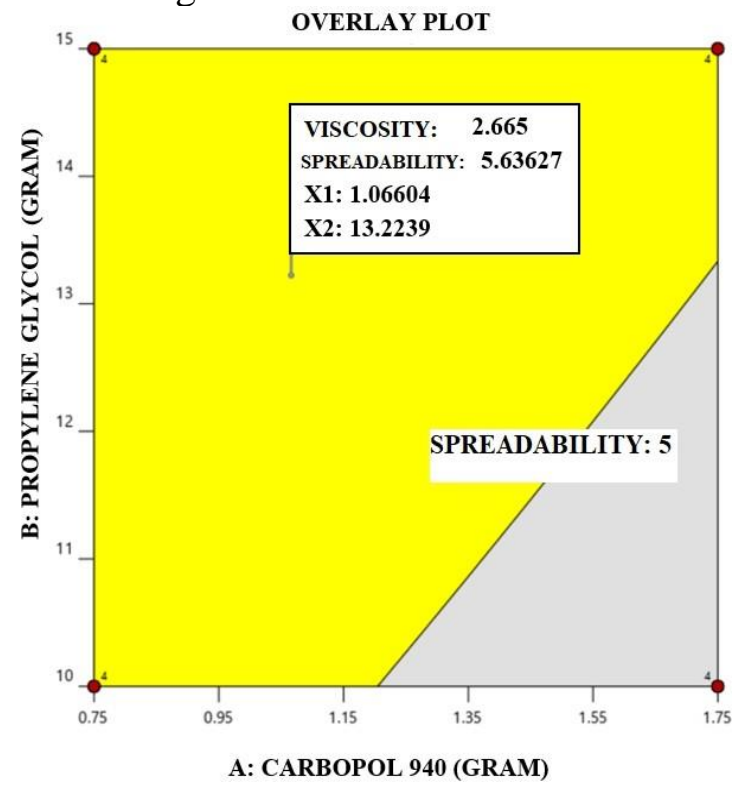

Figure 2. Overlay plots response of viscosity and spreadability of papaya seed ethanol extract gel

Figure 2 shows the plot overlays obtained from the results of the viscosity response and spreadability response plots. Grey areas indicate that there is a formula which has a spreadability value that is not included in the criteria for good spreadability or below $5 \mathrm{~cm}$, namely formula A because the composition of carbopol 940 used in the formula is at a high level (1.75 gram) while propylene glycol composition at a low level (10 grams) which causes the effect of the carbopol 940 factor is more dominant and produces a low dispersion value. to find out the composition of carbopol 940 and propylene glycol which can produce gel preparations with good physical properties and stability can be done by right clicking then selecting the add flag option in the yellow area. In this research, 1.04060 grams of carbopol 940 and 13.2146 grams of propylene glycol are known to produce gel preparations with good physical properties and stability. 


\section{CONCLUSION}

The gel of papaya (Carica papaya L.) seed ethanol extract with good physical properties and stability were obtained on the use of carbopol 940 and propylene glycol as much as 1.0660 grams and 13.2146 grams respectively. In addition, it was found that the carbopol 940 was the dominant factor in influencing the viscosity and spreadability response with contributed $92.509 \%$ in influencing the viscosity response and $59.539 \%$ in influencing the spreadability response, while the dominant factor in determining the viscosity shift response was the interaction the two factors were carbopol 940 and propylene glycol which the contribution was $60.446 \%$.

\section{ACKNOWLEDGEMENT}

The authors thanks to Research Institutions and Community Services (LPPM) of Sanata Dharma University.

\section{REFERENCES}

Allen L.V., and Ansel, H.C., 2002. The Art, Science, and Technology of Pharmaceutical Compounding.

American Pharmaceutical Association.

Andriyani, D., Utami, P. I., Dhiani, B.A.,2010.

Penetapan Kadar Tanin Daun

Rambutan (Nephelium lappaceum.L) Secara Spektrofotometri Ultraviolet Visibel. Pharmacy, 7(2), 1-11.

Arikumalasari, J., Dewantara, I.G.N.A., and Wijayanti, N.P.A.D., 2013. Optimasi HPMC sebagai Gelling Agent dalam Formula Gel Ekstrak Kulit Buah Manggis (Garcinia mangostana L.). Jurnal Farmasi Udayana, 145-152.

BPOM RI., 2010. Pembuatan Sediaan Herbal. In: Direktorat Obat Asli Indonesia. edisi Kelima. Badan Pengawas Obat dan Makanan Republik Indonesia, Jakarta. pp. 7.

Davis, W.W. and Stout, T.R., 1971. Disc plate method of microbiological antibiotic assay. Applied Microbiology, 22(4), 659-665.

Kementerian Kesehatan RI, 2013. Farmakope Herbal Indonesia: Kementerian kesehatan. pp. 47.
Hayatie, L., Biworo, A., and Suhartono E., 2015. Aqueous Extracts of Seed and Peel of Carica papaya gainst A Aedes Aegypti. Journal of Medical and Bioengineering, 4(5), 418-419.

Hudzicki, 2016. Kirby-Bauer Disk Diffusion Susceptibility Test Protocol. American Society for Microbiology. 17-18.

Ikalinus, R., Widyasstuti, S.K., and Setiasih, N.L.E., 2015. Phytochemical Screening Ethanol Extract Skin Stem Moringa (Moringa Oleifera). Indonesia Medicus Veterinu, 4(1), 7179.

Lohidas, J., Manjusha, S., and Jothi, G.G.G., 2015. Antimicrobial Acivities of Carica papaya L. Plant Archives, 15(2), 1179-1186.

Menteri Kesehatan RI, 2011. Pedoman Umum Penggunaan Antibakteri. Jakarta. Peraturan Menteri Kesehatan Republik Indonesia, pp.1.

Muharni, Fitrya, and Farida S., 2017. Antibacterial Assay of Ethanolic Extract Musi Tribe Medicinal Plant in Musi Banyuasin, South Sumatera. Jurnal Kefarmasian Indonesia, 7(2), 127-135.

Nismawati, Sjahril, R., and Agus, R., 2018. Deteksi Methicillin Resistant Staphylococcus aureus (MRSA) Pada Pasien Rumah Sakit Universitas Hasanuddin Dengan Metode Kultur. Prosiding Seminar Nasional Megabiodiversitas Indonesia, FK UNHAS 2018, 16.

Patel, N., Patel, P., Patel, D., Desai, S., and Meshram, D., 2014. Phytochemical Analysis and Antibacterial Activity of Moringa oleifera. International journal of medicine and pharmaceutical sciences (IJMPS), 4(2), 27-34.

Rowe, R.C., Sheskey, P.J., and Quinn, M.E., 2009. Handbook of Pharmaceutical Excipients: Pharmaceutical Press. $6^{\text {th }}$ Edition, London.

Sayuti, N.A., 2015. Formulasi dan Uji Stabilitas Fisik Sediaan Gel Ekstrak 
Daun Ketepeng Cina (Cassia alata L.). Jurnal Kefarmasian Indonesia, 5 (2), 75.

Salman, Rustini, Purnomo, H., 2012. Formulasi Obat Jerawat Gel Minyak Atsiri Daun Jeruk Purut (Cytrus Hystrix D.C) Dan Uji Aktivitas Terhadap Propionibacterium Acne Secara in Vitro. pp. 3-4.

Sarlina, Razak, A.R., and Tandah, M.R., 2017. Uji Aktivitas Antibakteri Sediaan Gel Ekstrak Daun Sereh (Cymbopogon nardus L. Rendle) terhadap Bakteri Staphylococcus aureus Penyebab Jerawat. Galenika Journal of Pharmacy, 3(2), 143-149.
Setiawati, A., 2015. Peningkatan Resistensi Kultur Bakteri Staphylococcus aureus terhadap Amoxicillin Menggunakan Metode Adaptif Gradual. Jurnal Farmasi Indonesia, 7 (3), 191.

Tantri, G.K.D., Widiharih, T., and Wuryandari, T., 2015. Analisis Desain Faktorial Fraksional 2 $2^{\mathrm{k}-\mathrm{p}}$ dengan Metode Lenth. Jurnal Gaussian, 4(3), 1.

Torar, G.M. J., Lolo, W.A., and Citraningtyas G., Uji Aktivitas Antibakteri Ekstrak Etanol Biji Pepaya (Carica papaya L.) Terhadap Bakteri Pseudomonas Aeruginosa dan Staphylococcus aureus. Pharmacon Jurnal Ilmiah Farmasi, 6(2), 14-21. 